\title{
SUBSTRATES FORMULATED WITH ORGANIC RESIDUES IN THE PRODUCTION OF SEEDLINGS OF Moquiniastrum polymorphum
}

\author{
Júlio Cézar Tannure Faria ${ }^{1}$, Lucas Amaral de Melo ${ }^{1}$ Gilvano Ebling Brondani ${ }^{1}$ William Macedo Delarmelina ${ }^{2}$, \\ Diana Suzete Nunes da Silva ${ }^{1}$, Erick Martins Nieri ${ }^{1}$ \\ ${ }^{1}$ Universidade Federal de Lavras (UFLA) jc.tannure@gmail.com*; lucas.amaral@dcf.ufla.br; gilvano.brondani@dcf.ufla.br; \\ disuzeteflorestal@gmail.com; ericknieri123@gmail.com \\ ${ }^{2}$ Universidade Federal do Espírito Santo (UFES) williammdelarmelina@gmail.com;
}

Recebido para publicação: 08/02/2017 - Aceito para publicação: 07/10/2017

\begin{abstract}
The composition of the substrate utilized as a growth medium is directly related to the seedling quality, being important the conduction of studies seeking an increased understanding of its formulation for seedling production. The objective of this study was to check the potential of the biosolid, cattle manure and coconut fiber in the evaluation of different substrate formulations for the production of seedlings of the forest species Moquiniastrum polymorphum. The experiment was conducted in structures of a forest nursery, localized in the municipality of Lavras-MG, in $110 \mathrm{~cm}^{3}$ tubes arranged in a completely randomized design constituted by five treatments with four replications of 54 seedlings per plot. When the seedlings reached 150 days after sowing, plant height, collet diameter, height/diameter ratio, shoot dry mass, root system dry mass, total dry mass and the shoot/root dry mass were measured, in addition to the Dickson Quality Index - DQI. It was found by means of the results obtained that for the production of seedlings of $M$. polymorphum, the use of substrates formulated from 20 to $60 \%$ of biosolid +20 to $60 \%$ of cattle manure $+20 \%$ of coconut fiber is recommended.

Keywords: Biosolid; Gochnatia polymorpha; seedling quality; silviculture; forest nursery.
\end{abstract}

\section{Resumo}

Formulação de substrato com resíduos orgânicos na produção de mudas de Moquiniastrum polymorphum. A composição do substrato utilizado como meio de crescimento está diretamente relacionada com a qualidade de mudas, sendo importante a realização de estudos que busquem uma maior compreensão de sua formulação para produção de mudas. O objetivo deste estudo foi verificar o potencial do uso do biossólido, esterco bovino e fibra de coco na avaliação de diferentes formulações de substratos para a produção de mudas da espécie florestal Moquiniastrum polymorphum. O experimento foi conduzido no Viveiro Florestal da Universidade Federal de Lavras (UFLA), em tubetes de $110 \mathrm{~cm}^{3}$, sendo instalado em um delineamento inteiramente casualizado constituído por cinco tratamentos, com quatro repetições de 54 mudas por parcela. Quando as mudas atingiram 150 dias após a semeadura, foram mensurados a altura das plantas, o diâmetro do coleto, a relação altura/diâmetro, a massa seca da parte aérea, a massa seca do sistema radicular, a massa seca total e a relação massa seca da parte aérea/raiz, além do índice de qualidade de Dickson (IQD). Por meio dos resultados obtidos, constatou-se que para a produção de mudas de $M$. polymorphum recomenda-se o uso de substratos formulados a partir de 20 a $60 \%$ de biossólido +20 a $60 \%$ de esterco bovino $+20 \%$ de fibra de coco.

Palavras-chave: Biossólido; Gochnatia polymorpha; qualidade de mudas; silvicultura; viveiro florestal.

\section{INTRODUCTION}

The production of native seedlings in Brazil presents restrictions that prevent their increase on the commercial scale such as the lack of theoretical and practical knowledge of a number of forest species of our ecosystems, making it difficult to find nurseries with both diversity and amounts necessary for the restoration and/or recovery of certain areas. In this sense, constantly, works have been carried out aimed at the production of seedlings of native forest species in the attempt to minimize such problems (CARLOS et al., 2014).

The forest species Moquiniastrum polymorphum (Less.) G. Sancho (previously called Gochnatia polymorpha), known as cambará or candeia, is a species belonging to the family Asteraceae, pioneer or early secondary, found in a series of floristic surveys of the Cerrado and Atlantic Forest, but little studied concerning its process of seedling production, which shows important characteristics for early composition in reforestations of degraded areas, such as anemochorous dispersal, fauna-attractive, fire-resistance and regrowth capacity (MACHADO et al., 2015). 
In seedling production, one of the factors to be studied is the formulation of substrates that meet the needs of the plants that will be produced. There are different organic materials utilized as substrates, such as organic compounds, cattle manure, rice chaff and biosolids, among others (SANTOS et al., 2014).

In the process of forest seedling production, the use of biosolids has been a viable alternative for the supply of organic matter and nutrients in substrate formulation (FARIA et al. 2013). However, since biosolid may contain high concentrations of contaminants, that practice may result into addition of several pathogens, unwished chemicals in farming soils and consequently in the food chain, so care has to be taken in its application following the patterns imposed by the current legislation of the Resolution CONAMA - 375/2006 (National Council for the Environment) (BRASIL, 2006).

Cattle manure is another organic residue with a great potential as a substrate in the furnishing of organic materials for seedlings, for it contributes to the improvement of physical, chemical and biological conditions of soil, in the rise of cation exchange capacity and in the retention of moisture and nutrients, like nitrogen (TRAZZI et at., 2012).

Presenting important characteristics to the physical composition in the substrate constitution, coconut fiber is a lightweight residue, granular and homogeneous structured, with high total porosity and aeration capacity, in addition to presenting low cost for being a residue of the commercial exploration of coconut water (DIAS et al., 2009).

Based on the aforementioned, the hypothesis of the present study was that the organic residues biosolid, cattle manure and coconut fiber contribute positively to the production of seedlings of the forest specie $M$. polymorphum. In this sense, the objective was to evaluate the use potential these three organic residues as components of the substrate for production of seedlings of $M$. polymorphum, as well as its chemical and physical properties.

\section{MATERIAL AND METHODS}

\section{Site}

The seedlings of $M$. polymorphum were produced in structures of a forest nursery, localized in the municipality of Lavras-MG, during the period of July to December of 2015. In agreement with the Köppen classification, the climate of the region that the experiment was conducted fits in the Cwb type, the average yearly temperature being of $20.4^{\circ} \mathrm{C}$ and yearly rainfall of 1,460 mm (ALVARES et al., 2013). In table 1 are presented the average climate data of temperature, rainfall, humidity and wind speed during each month of the conduction of the experiment.

Table 1. Monthly values in temperature, rainfall, relative humidity, wind speed of the town of Lavras (MG).

Tabela 1. Valores mensais da temperatura média, precipitação acumulada, umidade relativa do ar, velocidade do vento na cidade de Lavras (MG).

\begin{tabular}{lcccc}
\hline \multirow{2}{*}{ Months } & Average temperature & Total rainfall & Average humidity & Wind speed (mean) \\
\cline { 2 - 5 } & ${ }^{\circ} \mathbf{C}$ & $\mathbf{~ m m}$ & $\mathbf{\%}$ & $\mathbf{m . s}$ \\
\hline July & 18.3 & 1.7 & 70.5 & 2.0 \\
August & 19.0 & 36.6 & 60.7 & 1.9 \\
September & 22.5 & 117.4 & 65.3 & 1.8 \\
October & 25.8 & 22.7 & 57.4 & 2.0 \\
November & 24.5 & 273.8 & 75.2 & 1.6 \\
December & 24.3 & 60.3 & 74.4 & 1.4 \\
\hline
\end{tabular}

\section{Acquisition and guideline of use of the substrates}

The substrates were formulated by utilizing three sorts of organic components, namely: biosolid (BIO), cattle manure $(\mathrm{CM})$ and coconut fiber $(\mathrm{CF})$.

The biosolid utilized was coming from the Estação de Tratamento de Esgoto Alegria (Alegria Sewage Treatment Station), situated in Caju neighborhood (bairro Caju), Rio de Janeiro-RJ. The material was donated by Companhia Estadual de Águas e Esgoto do Rio de Janeiro (CEDAE) (State Water and Sewage Company). The ETEtreated sewage is derived from residential and commercial urban areas, obtained by anaerobic digestion process.

The biosolid is the commercial names of sewage sludge after undergoing a process of stabilization, which constitutes the solid part of the sewage. This residue can be used as a conditioner of the physical, chemical and biological properties of the substrate, considering its content of organic matter and nutrient (ABREU et al., 2017).

Based on the demand imposed in the resolution CONAMA n³75/2006 (BRASIL, 2006), the biosolid met the parameters relative to the concentration of the pathogenic agents and bacteriologic indicators, being 
classified as class A. The biosolid met also the parameters relative to the chemical composition stipulated by the legislation, being suitable for use in agricultural environments (Table 2).

The cattle manure was donated by the farmers near the study region. That material was collected in dairy cow corrals, having as the main feed the natural grazing land. Coconut fiber utilized was "Golden Mix Fibroso", purchased from Amafibra Company, which presented rough texture, manufactured from the coconut mesocarp. In agreement with the information reported on the product label, that substrate presents water-holding capacity of $300 \mathrm{~mL}$ per liter, total porosity of $95 \%$ and weight of $150 \mathrm{~kg}$ per $\mathrm{m}^{3}$.

Table 2. Concentration of the inorganic substances and of the different indicator elements of the agronomic potential in the biosolid coming from the Alegria, ETE Rio de Janeiro (RJ).

Tabela 2. Concentração de elementos químicos e indicadores do potencial agronômico no biossólido proveniente da ETE Alegria, Rio de Janeiro (RJ).

\begin{tabular}{|c|c|c|}
\hline Elements & Analitic ${ }^{1}$ Results & Resolution number 375/2006 CONAMA ${ }^{2}$ \\
\hline (As) Arsenic & $<2.6 \mathrm{mg} \cdot \mathrm{kg}^{-1}$ & $41 \mathrm{mg} \cdot \mathrm{kg}^{-1}$ \\
\hline (Ba) Barium & $157 \mathrm{mg} \cdot \mathrm{kg}^{-1}$ & $1300 \mathrm{mg} \cdot \mathrm{kg}^{-1}$ \\
\hline (Cd) Cadmium & $<0,2 \mathrm{mg} \cdot \mathrm{kg}^{-1}$ & $39 \mathrm{mg} \cdot \mathrm{kg}^{-1}$ \\
\hline$(\mathrm{Pb})$ Lead & $197 \mathrm{mg} . \mathrm{kg}^{-1}$ & $300 \mathrm{mg} \cdot \mathrm{kg}^{-1}$ \\
\hline (Cu) Copper & $267 \mathrm{mg} \cdot \mathrm{kg}^{-1}$ & 1500 mg.kg ${ }^{-1}$ \\
\hline (Cr) Chromium & $70 \mathrm{mg} \cdot \mathrm{kg}^{-1}$ & $1000 \mathrm{mg} \cdot \mathrm{kg}^{-1}$ \\
\hline (Hg) Mercury & $<0.03 \mathrm{mg} \cdot \mathrm{kg}^{-1}$ & 17 mg.kg-1 \\
\hline (Mo) Molibdenium & $22.6 \mathrm{mg} . \mathrm{kg}^{-1}$ & $50 \mathrm{mg} \cdot \mathrm{kg}^{-1}$ \\
\hline (Ni) Nickel & $40.2 \mathrm{mg} \cdot \mathrm{kg}^{-1}$ & $420 \mathrm{mg} \cdot \mathrm{kg}^{-1}$ \\
\hline (Se) Selenium & $<5.9 \mathrm{mg} \cdot \mathrm{kg}^{-1}$ & 100 mg.kg ${ }^{-1}$ \\
\hline (Zn) Zinc & 681 mg.kg-1 & 2800 mg.kg ${ }^{-1}$ \\
\hline Total phosphorus & $0.62 \%$ & - \\
\hline Total potassium & $0.50 \%$ & - \\
\hline Total sodium & $0.16 \%$ & - \\
\hline Total sulfur & $1.20 \%$ & - \\
\hline Total nitrogen & $3.88 \%$ & - \\
\hline Kjeldahl nitrogen & $33.497 \mathrm{mg} . \mathrm{kg}^{-1}$ & - \\
\hline Amoniacal nitrogen & $208 \mathrm{mg} \cdot \mathrm{kg}^{-1}$ & - \\
\hline Nitrite & $17 \mathrm{mg} \mathrm{N} \cdot \mathrm{kg}^{-1}$ & - \\
\hline Nitrate & $5.318 \mathrm{mg} \mathrm{N} \cdot \mathrm{kg}^{-1}$ & - \\
\hline Total solids & $74.29 \%$ & - \\
\hline Volatile solids & $24.29 \%$ & - \\
\hline $\mathrm{pH}$ in water $(1: 10)$ & 5.45 & - \\
\hline
\end{tabular}

Before the mixing of the components, both biosolid and cattle manure remained exposed in full sunshine, open place for about 60 days for biological stabilization, being revolved every seven days. Afterwards, both the materials were past through a steel sieve with a $3.70 \mathrm{~mm}$ mesh (6 MPL - mesh per linear inch) for homogenization of the particles.

The treatments were formulated by mixing by hand the three organic residues in the following proportions: Treatment $1=80 \% \mathrm{BIO}+20 \% \mathrm{CF}$; Treatment $2=60 \% \mathrm{BIO}+20 \% \mathrm{CM}+20 \% \mathrm{CF}$; Treatment $3=$ $40 \% \mathrm{BIO}+40 \% \mathrm{CM}+20 \% \mathrm{CF}$; Treatment $4=20 \% \mathrm{BIO}+60 \% \mathrm{CM}+20 \% \mathrm{CF}$ and; Treatment $5=80 \% \mathrm{CM}+$ $20 \%$ CF. To measure the volumes necessary of the components that were mixed, a graduated plastic bucket with a capacity of $10 \mathrm{~L}$ was used and after they were homogenized, samples of each substrate were separated for later conduction of the chemical and physical analyses.

\section{Seeds and seedling conduction}

The seeds of $M$. polymorphum were acquired from Sementes Caiçara Company, was processed from the removal of the structure of anemochoric dispersal and later separation by means of the seed blower of the General type, regulated at opening 5 for 30 seconds. Afterwards, the hand sowing utilizing about three to five seeds per container was performed. To warrant a good supply of nutrients, $4 \mathrm{~kg}$ per $\mathrm{m}^{3}$ of Basacote Mini 3M 1306-16 fertilizer $(+1.4)$ were added to the formulation of the substrates.

The sowing was carried out in tubes with the capacity for $110 \mathrm{~cm}^{3}$ of substrate, placed onto polypropylene trays with the capacity of 108 units, these trays being arranged on beds suspended $80 \mathrm{~cm}$ away from the ground in screen-covered shade house allowing passage of $50 \%$ of luminosity. 
The seedlings remained in shaded environment for 30 days. After that period, the seedlings were taken to the full sunshine area, remaining 120 days in this place till hardening. Thinning was conducted with the aid of a pair of scissors after 60 days from sowing, leaving one seedling per container, that being more centralized and with better growth of the shoot.

The topdressing occurred 70 days after sowing, utilizing 1,000 g Krista ${ }^{\mathrm{TM}} \mathrm{MAP}\left(12 \% \mathrm{~N}, 61 \% \mathrm{P}_{2} \mathrm{O}_{5}\right)$, $150 \mathrm{~g} \mathrm{KCl}\left(58 \% \mathrm{~K}_{2} \mathrm{O}\right)$, diluted in 100 liters of water, $10 \mathrm{~mL}$ of this solution being applied per seedling.

The reduction of seedling densit of the seedlings was carried out at 110 days after sowing with the purpose of reducing competition and increasing spacing between the seedlings. Irrigation was by sprinkling with automatic system, with $10 \mathrm{~mm}$, being irrigated four times a day (two in the morning and two in the afternoon) and interrupted on rainy days.

\section{Chemical and physical analysis of the substrates}

The physical and chemical characterization of the substrates was carried out in the Horticulture and Silviculture Department Substrate Laboratory (Laboratório de Substratos do Departamento de Horticultura e Silvicultura) at the Federal University of Rio Grande do Sul (Universidade Federal do Rio Grande do Sul).

For the chemical analyses, the evaluations of electrical conductivity (EC) and hydrogen potential $(\mathrm{pH})$ were considered in a dilution substrate: water of 1:5 (v: v), in agreement with the IN number 17, of May 21, 2007 which establishes the methods for analysis of substrate for plants. All the analyses were carried out with three replications of the substrate in each treatment.

For physical analysis, the following evaluations were taken into consideration: wet density (WD), dry density (DD), current moisture (CM), total porosity (TP), aeration space (AS), easily available water (EAW), buffering water $(\mathrm{BW})$, remaining water $(\mathrm{RW})$ and water-holding capacity under suction of 50 -and $100 \mathrm{~cm}$ water column, determined in volumetric basis (WHC).

The determination of the density was performed by means of the Self-Compaction Method and the water-holding curves at the tensions of $0 ; 10 ; 50$ and $100 \mathrm{hPa}$, were determined in tension funnels, according to the De Boodt and Verdonck (1972) principles.

\section{Morphological characteristics of the seedlings}

When the seedlings reached 150 days after sowing, the following morphological characteristics were measured: shoot height $(\mathrm{H})$, collet diameter (D), ratio between height and collet diameter (RHD), shoot dry mass (SDM), root system dry mass (RDM), total dry mass (TDM), ratio between shoot dry mass and root system dry mass (RSR) and Dickson Quality Index (DQI).

Height was obtained with the aid of a ruler with millimeter markings, taking as the standard the terminal bud (apical meristem) and the collet diameter was measured by means of a digital pachymeter with precision of $0.01 \mathrm{~mm}$. For obtaining of the shoot dry mass and root system dry mass, weighing of the plant parts was carried out apart after the drying of them in a forced air circulation oven at $70^{\circ} \mathrm{C}$ for a period of about $72 \mathrm{~h}$. DQI was obtained using the formula (DICKSON et al., 1960):

$$
\mathrm{DQI}=\mathrm{TDM}_{(\mathrm{g})} /\left[\left(\mathrm{H}_{(\mathrm{cm})} / \mathrm{D}_{(\mathrm{mm})}\right)+\left(\mathrm{SDM}_{(\mathrm{g})} / \mathrm{RDM}_{(\mathrm{g})}\right)\right]
$$

In which: $\operatorname{TDM}(\mathrm{g})=$ Total dry mass; $\mathrm{H}(\mathrm{cm})=$ Shoot height; $\mathrm{D}(\mathrm{mm})=$ Collet diameter; $\operatorname{SDM}(\mathrm{g})=\mathrm{Dry}$ mass of the shoot; $\operatorname{RDM}(\mathrm{g})=$ Dry mass of the root system.

\section{Experimental design and statistical analysis}

The experiment was installed in a completely randomized statistical design (DIC), constituting five treatments, with four replications of 54 seedlings per plot. For evaluation of the growth of seedlings of $M$. polymorphum, the data obtained were submitted to the analysis of variance (ANOVA) and when significances were detected by the F test, the means were compared by the Scott-Knott test at the level of 5\% of probability of error. The principal component analysis (PCA) was carried out in the correlation matrix. The accumulated variance greater than $80 \%$ was utilized as a criterion for PCA. The statistical analyses were carried out with the aid of R program, Version 3.0.2.

\section{RESULTS}

The results of the chemical and physical results of the substrates formulated for the production of seedlings of $M$. polymorphum are presented in table 3 . Relative to the chemical analyses of the substrates, the average results of $\mathrm{pH}$ ranged between 4.18 and 7.98. It is found that the $\mathrm{pH}$ values decreased as the proportions of biosolid were increased and those of cattle manure were reduced. For electrical conductivity, the results of the 
substrates ranged between 1.57 to $4.02 \mathrm{mS} . \mathrm{cm}^{-1}$. Inversely proportional to $\mathrm{pH}$, the values of the electrical conductivity increased as the proportions of the biosolid were added to the substrate formulations (Table 3).

Table 3. Chemical (pH and EC) and Physical Analysis of the substrate formulated in the production of seedlings of $M$. polymorphum.

Tabela 3. Análise química (pH e EC) e física dos substratos formulados na produção de mudas de $M$. polymorphum.

\begin{tabular}{lllllll}
\hline \multirow{2}{*}{ Analysis } & \multirow{2}{*}{ Unit } & \multicolumn{5}{c}{ Treatments } \\
\cline { 3 - 6 } & & T1 & T2 & T3 & T4 & T5 \\
\hline pH & $\mathrm{H}_{2} \mathrm{O}$ & 4.18 & 5.28 & 6.33 & 6.83 & 7.98 \\
EC & $\mathrm{mS} \cdot \mathrm{cm}^{-1}$ & 4.02 & 3.52 & 2.81 & 2.37 & 1.57 \\
WD & $\mathrm{Kg} \cdot \mathrm{m}^{-3}$ & 528.43 & 534.28 & 505.54 & 492.21 & 505.02 \\
DD & $\mathrm{Kg} \cdot \mathrm{m}^{-3}$ & 349.18 & 330.39 & 303.92 & 299.15 & 293.98 \\
CM & $\%$ & 33.92 & 38.16 & 39.88 & 39.23 & 41.79 \\
TP & $\%$ & 82.60 & 83.39 & 84.18 & 84.15 & 86.16 \\
AS & $\%$ & 18.54 & 16.90 & 18.14 & 16.53 & 17.27 \\
EAW & $\%$ & 27.10 & 29.26 & 29.19 & 30.00 & 28.76 \\
BW & $\%$ & 5.89 & 4.75 & 3.12 & 2.50 & 1.73 \\
RW & $\%$ & 31.06 & 32.39 & 33.73 & 34.91 & 38.40 \\
WHC (10) & $\%$ & 64.06 & 66.40 & 66.04 & 67.63 & 68.89 \\
WHC (50) & $\%$ & 36.96 & 37.14 & 36.85 & 37.41 & 40.13 \\
WHC (100) & $\%$ & 31.06 & 32.39 & 33.79 & 34.91 & 38.40 \\
\hline
\end{tabular}

T1:80\%BIO+20\%CF; T2:60\%BIO+20\%CM+20\%CF; T3:40\%BIO+40\%CM+20\%CF; T4:20\%BIO+60\%CM+20\%CF; T5:80\%CM+20\%CF $\mathrm{pH}=$ determined in water, dilution 1:5 (v/v); EC = electrical conductivity obtained in solution 1:5 (v/v); WD = wet density; DD = dry density; $\mathrm{CM}=$ current moisture; $\mathrm{TP}=$ total porosity; $\mathrm{AS}=$ Aeration space; EAW = easily available water; $\mathrm{BW}=$ buffering water; $\mathrm{RW}=$ remaining water; WHC 10,50 and $100=$ water holding capacity under suction of 10,50 and $100 \mathrm{~cm}$ of water column determined in volumetric basis; $\mathrm{AW}=$ available water which can be obtained by the sum of EAW $+\mathrm{BW}$.

As regards the physical properties of the substrates, the average values in wet density presented a low ratio with dry density. It is found in Table 3 that the increase of the dry density occurred as greater proportions of biosolid were added to the substrate formulations. For the total porosity, the formulated substrates varied their results between $82.60 \%$ and $86.16 \%$. All treatments presented values of aeration space less than $20 \%$ and waterholding capacity, under suction of $10 \mathrm{~cm}$ of water column, above $50 \%$. The substrate formulated in $\mathrm{T} 5$ presented the greatest values in the three evaluations of the water column for the WHC.

Concerning the amount of easily available water (EAW), the substrates presented values close to $30 \%$. As regards the criterion buffering water, its values ranged between 1.73 and $5.98 \%$. At last, the remaining water (RW) of the formulated substrates ranged between 31.06 and 38.40, T5 presenting the greatest average result (Table 3).

After the interpretation of the chemical and physical analyses of the substrates, the morphological parameters of the seedlings of $M$. polymorphum were evaluated. It is found in Table 4 which the seedlings produced in the substrates with the addition of biosolid, cattle manure and coconut fiber presented statistically superior results in the morphological characteristics when compared with those of the treatments formulated only with two organic residues (T1 and T5).

The characteristic height of the shoot of the seedlings of $M$. polymorphum showed statistically significant differences among the treatments studied, with average values ranging from 6.55 to $17.95 \mathrm{~cm}$. The seedlings of treatments T2, T3 and T4 showed the highest average height, being statistically superior to the other treatments.

As regards the morphological characteristic collet diameter, the seedlings of $M$. polymorphum presented the highest average result equal to $3.20 \mathrm{~mm}$. As well as to height of the shoot, again, the seedlings of treatments T2, T3 and T4 presented the greatest growth means and the seedlings of T5 did the lowest mean (Table 4).

For the RHD ratio and the Dickson quality index, the greatest average values of M. polymorphum were observed by treatments T2, T3 and T4. The treatments T1 and T5 provided the lowest statistical averages for both morphological characteristics (Table 4).

As far as the dry mass of the shoot is concerned, the seedlings of $M$. polymorphum presented their average values ranging from 0.469 to $2.485 \mathrm{~g}$ per plant, the greatest results being expressed in treatment $\mathrm{T} 3$ and T4, both statistically equal. Assessing the root dry mass of seedlings of M. polymorphum, the treatments which presented the highest means were T2, T3 and T4, not differing statistically from one another. The lowest averages for both shoot dry mass, and root dry mass were presented by treatment T5, consisting of $80 \%$ of cattle manure plus $20 \%$ of coconut fiber (Table 4). 
The total dry mass of treatments T3 and T4 were the ones that showed the highest average values, while T5 showed the lowest mean, with value equal to $0.95 \mathrm{~g}$ per plant (Table 4$)$. This characteristic resulted from the sum between the dry mass of the shoot, and root dry mass. The variation between the highest $(4.08 \mathrm{~g})$ and the lowest $(0.95 \mathrm{~g})$ absolute total dry mass was $3.13 \mathrm{~g}$, demonstrating again as the substrate composition influenced directly the shoot and root growth of the seedlings of $M$. polymorphum.

For the ratio between the shoot dry mass and root dry mass (RSR), all treatments in the present study resulted in average values lower than 2 . The treatments that resulted in the highest averages were T2, T3 and T4, and the treatments T1 and T5 were the lowest averages, according to the Scott-Knott test (p-value > 0,05).

Table 4. Shoot Height (H), collet diameter (D), ratio height/diameter (RHD), Dickson Quality Index (DQI) Shoot dry mass (SDM), root system dry mass (RDM), total dry mass (TDM), ratio between shoot dry mass and root system dry mass (RSR) of the seedlings of $M$. polymorphum at 150 days after sowing.

Tabela 4. Altura (H), diâmetro do coleto (D), relação altura/diâmetro (RHD, índice de qualidade de Dickson (DQI) Massa seca da parte aérea (SDM), massa seca radicular (RDM), massa seca total (TDM) e relação massa seca da parte aérea/raiz (RSR) das mudas de $M$. polymorphum aos 150 dias após a semeadura.

\begin{tabular}{lcccccccc}
\hline Treataments & H $(\mathbf{c m})$ & D $(\mathbf{m m})$ & RHD & DQI & SDM $(\mathbf{g})$ & RDM $(\mathbf{g})$ & TDM $(\mathbf{g})$ & RSR \\
\hline T1 $(80 \% \mathrm{BIO}+20 \% \mathrm{CF})$ & $8.46 \mathrm{~b}$ & $2.62 \mathrm{~b}$ & $3.21 \mathrm{~b}$ & $0.37 \mathrm{~b}$ & $0.794 \mathrm{c}$ & $0.796 \mathrm{~b}$ & $1.590 \mathrm{c}$ & $0.99 \mathrm{~b}$ \\
\hline $\mathrm{T} 2(60 \% \mathrm{BIO}+20 \% \mathrm{CM}+20 \% \mathrm{CF})$ & $17.34 \mathrm{a}$ & $3.16 \mathrm{a}$ & $5.48 \mathrm{a}$ & $0.49 \mathrm{a}$ & $2.074 \mathrm{~b}$ & $1.370 \mathrm{a}$ & $3.444 \mathrm{~b}$ & $1.62 \mathrm{a}$ \\
\hline T3 $(40 \% \mathrm{BIO}+40 \% \mathrm{CM}+20 \% \mathrm{CF})$ & $17.95 \mathrm{a}$ & $3.20 \mathrm{a}$ & $5.60 \mathrm{a}$ & $0.57 \mathrm{a}$ & $2.485 \mathrm{a}$ & $1.600 \mathrm{a}$ & $4.085 \mathrm{a}$ & $1.65 \mathrm{a}$ \\
\hline T4 $(20 \% \mathrm{BIO}+60 \% \mathrm{CM}+20 \% \mathrm{CF})$ & $16.99 \mathrm{a}$ & $3.12 \mathrm{a}$ & $5.42 \mathrm{a}$ & $0.53 \mathrm{a}$ & $2.335 \mathrm{a}$ & $1.477 \mathrm{a}$ & $3.812 \mathrm{a}$ & $1.71 \mathrm{a}$ \\
\hline $\mathrm{T} 5(80 \% \mathrm{CM}+20 \% \mathrm{CF})$ & $6.57 \mathrm{c}$ & $2.12 \mathrm{c}$ & $3.08 \mathrm{~b}$ & $0.23 \mathrm{c}$ & $0.469 \mathrm{~d}$ & $0.482 \mathrm{c}$ & $0.951 \mathrm{~d}$ & $0.92 \mathrm{~b}$ \\
\hline $\mathrm{CV}(\%)$ & 10.25 & 9.05 & 12.89 & 16.69 & 8.98 & 9.58 & 7.81 & 9.04 \\
\hline
\end{tabular}

Biosolid (BIO), cattle manure (CM) and coconut fiber (CF). Means followed by the same letter in the column do not differ statistically from one another by the Scott-Knott test $(\mathrm{p}>0.05)$.

With regard the principal component analysis (PCA), the distribution of the observations of each treatment, resulted of the interaction between the two main components can be found. By analyzing axis 1 , concerning the first principal component, sharp separation among groups is noticed. On the left side of the vertical line passing through zero lie the observations of treatments T1 and T5 while on the right side the observations of the other treatments are lying. The highest correlations occurred between treatments T2, T3 and T4 with the characteristics H, D, RHD, SDM, RDM, TDM and DQI (Figure 1).

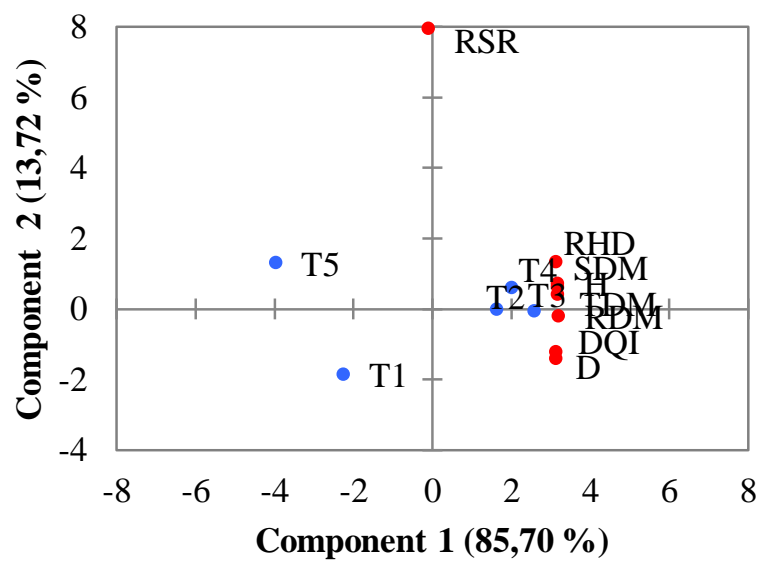

Figure 1. Projection of the two principal components showing the performance of the treatments in relation to the different morphological characteristics height $(\mathrm{H})$, collet diameter (D), RHD, Dickson quality index (DQI), shoot dry mass (SDM), root dry matter (RDM), RSR and total dry matter (TDM) on the growth of seedlings of $M$. polymorphum.

Figura 1. Projeção dos dois componentes principais mostrando o desempenho dos tratamentos em relação às diferentes características morfológicas altura (H), diâmetro do coleto (D), RHD, índice de qualidade de Dickson (DQI), massa seca parte aérea (SDM), massa seca radicular (RDM), relação massa seca da parte aérea e raiz (RSR) e massa seca total (TDM) no crescimento de mudas de M. polymorphum. 


\section{DISCUSSION}

\section{Chemical and physical analysis of the substrates}

In relation to $\mathrm{pH}$, only the $\mathrm{T} 3$ treatment presented substrate within the range proposed by Malavolta (2006), which considers the ideal $\mathrm{pH}$ between 5.5 and 6.5 , as it affects the availability of elements, especially some micronutrients. The substrate formulated in $\mathrm{T} 1$ resulted in $\mathrm{pH}$ value considered low, presenting acid character, while $\mathrm{T} 5$ presented $\mathrm{pH}$ value considered high, presenting basic character. Values below or above the limit regarded as adequate can cause problems in the seedling formation due to the unavailability of some nutrients and/or plant toxicity (MALAVOLTA, 2006).

It is found that the $\mathrm{pH}$ values decreased as the proportions of biosolid increased and those of cattle manure reduced (Table 3). Similar behaviors were found in the studies of Delarmelina et al. (2013) and Faria et al. (2013), both utilizing biosolid-based substrates, respectively, for production of seedlings of Sesbania virgata and Senna alata, which found that the $\mathrm{pH}$ values decreased as the proportions of biosolids increased.

Another chemical characteristic analyzed was the electrical conductivity of the substrate, in which all treatments presented values above the limit proposed by Gonçalves et al. (2000), which suggests not to exceed the limit of $1.0 \mathrm{mS} . \mathrm{cm}^{-1}$.

Regarding the physical characteristics of the substrates, all the treatments presented results thought of medium when dry density $\left(250\right.$ to $500 \mathrm{~kg} . \mathrm{m}^{-3}$ ) was evaluated and regarded as adequate for wet density (450 to $550 \mathrm{~kg} \cdot \mathrm{m}^{-3}$ ), according to values proposed by Gonçalves et al. (2000). In this way, formulations generating very dense substrates present smaller spaces between particles, which make both the gas exchanges and the water circulation difficult, offering greater resistance to root growth. On the other hand, decreased values of density are manifested into lightweight substrates, with poor carrying capacity for plants and poorer water holding capacity (SCIVITTARO et al., 2007).

With relation to total porosity, the substrate formulated at $\mathrm{T} 5$ was the only which obtained results above the adequate level in that criterion, the other substrates presented adequate density with values within the limit proposed by GONÇALVES et al., 2000. The elevated value of the total porosity in substrate T5, summed to the imbalance in macro and micropores, had as a consequence a poor distribution by air and water in the substrate, manifesting in this way into character harmful to the growth of the root system in seedling production.

Evaluating the division of total porosity, all the treatments presented low values for macroporosity (AS $<20 \%$ ) and values above the adequate for microporosity (WHC (10) > 50\%) (GONÇALVES et al., 2000). Although, total porosity is important, this should be interpreted in a fractioned manner into macro and microporosity to translate the physical quality of the substrate better. When the substrate is hydrically saturated, macropores are filled with air and their volume is defined as the aeration space (AS), whilst micropores are filled with water and this volume represents the water-holding capacity of a substrate (WHC) (ZORZETO et al. 2014).

In the current work, all the substrates formulated presented microporosity to a greater extent in the distribution of total porosity, pointing out substrates with increased probability of water saturation when irrigation was not adequately conducted. It is recommended to increase the percentage of coconut fiber in the composition of the substrates in order to provide better physical conditions of aeration and water retention.

Regarding the water retention capacity, the substrate in T5 influencing negatively the growth of the seedlings of M. polymorphum due to the greatest water retention in the substrate, resulting the greatest values in the three evaluations of the water column. In general, substrates with poorer water holding capacity require greater irrigation frequency or a greater volume of applied water (WENDLING et al., 2007), and substrates which present greater water holding capacity (greater microporosity) require increased rigorousness in irrigation control in order to avoid excess water and consequently $\mathrm{CO}_{2}$ accumulation and reduction of the root aeration (GONÇALVES et al., 2000).

Concerning the amount of easily available water (EAW), the substrates presented values inside the proposed limit, ranging between 20 and 30\% (DE BOODT; VERDONCK 1972). Gonçalves et al. (2000) stood out that materials with a low density raise the macroporosity of the mixtures and reduce the water-holding capacity of the substrate. In the current study, there was no correlation between the obtained results of EAW with the density. As regards the criterion buffering water, its values ranged between 1.73 and 5.98\%. De Boot and Verdonck (1972) estipulate as a reference value the percentage of BW between 4 and 10\%, only the substrates formulated in $\mathrm{T} 1$ and $\mathrm{T} 2$ lying inside this range (Table 3).

\section{Morphological characteristics of the seedlings}

In the present study, among the formulated substrates, the treatments $\mathrm{T} 2, \mathrm{~T} 3$ and $\mathrm{T} 4$ showed the highest heights and diameters and, consequently, were the most rustified in comparison to the other treatments. Up to the end of the experimental period (150 days after sowing), seedlings with excessive height problems were not 
found. Future studies are needed to evaluate survival in the field and indicate quality standards for $M$. polymorphum seedlings.

Relating research in the literature with the results of the current study, different species showed similar behavior in the initial growth using the same organic residues. The forest specie Chamaecrista desvauxii var. latistipula, under different compositions of organic substrates presents better initial growth on substrates containing cattle manure for most of the growth characteristics, including height and stem diameter (DELARMELINA et al., 2015). In seedlings of Peltophorobium dubim (Springer.) Taub., Lafoensia pacari A. St.-Hil., and Ceiba speciosa (A. St.-Hil.) Ravenna containing substrates 40 to $80 \%$ biosolids showed better growth of these two morphological characteristics (CABREIRA et al., 2017).

In the literature, the studies related to the forest species $M$. polymorphum are still few. Evaluating the growth of seedlings of this species under different formulations of substrates based on commercial substrate, carbonized rice husk and subsoil earth, Souza Junior et al. (2005) found average values for height between 5.8 and $8.4 \mathrm{~cm}$ at 150 days after transplanting. In the present study, treatments T2, T3 and T4 presented higher average growth, presenting average values between 17 and $18 \mathrm{~cm}$ at the same age. The treatments that resulted in the lowest average values (T1 and T5) were close to the results reported by the authors.

The RHD ratio and the Dickson quality index are very widespread morphological parameters in several scientific studies in the evaluation of the quality and production of agronomic and forest seedlings. It is worth mentioning that disagreement is found in the literature in the definition of the optimal values for these two magnitudes and they can vary according to the species of study, type and proportion of substrate, container volume, fertilization and evaluation age of the seedlings (CALDEIRA et al., 2013; DELARMELINA et al., 2013; STORCK et al., 2016). The RHD ratio of the seedlings of M. polymorphum ranged from 3.08 to 5.60, only treatments T2, T3 and T4 lying within the range considered ideal by Carneiro (1995), because it indicates values ranging between 5.4 and 8.1, that range being responsible for expressing the growth balancing between both the characteristics.

The Dickson quality index can be considered an important indicator of the quality of the seedlings, because for its calculation, the strength and balance of the distribution of biomass in the changes are taken into consideration, allowing grouping results of several important characteristics used to evaluate the quality of the seedlings (DICKSON et al., 1960). According to Caldeira et al. (2013), the greater the DQI value is, the better the quality of the seedling will be. Regarding the average values of DQI for seedlings of de M. polymorphum, treatments T2, T3 and T4 showed the highest means (Table 4). In seedlings of Handroanthus heptaphyllus (Vell.) Mattos containing substrates of 25 to $50 \%$ of biosolids presented better growth for this index (ABREU et al., 2017b). In seedlings of Chamaecrista desvauxii var. latistipula produced with a substrate formulated on the basis of $25 \%$ of commercial substrate, $40 \%$ of subsoil soil and $35 \%$ of bovine manure at 150 days, presented higher IQD (DELARMELINA et al., 2015).

For the analyses of the shoot dry mass and root system dry mass, Carneiro (1995) found that their growth is important to the support of the green biomass produced by plants. Growth is consequence of the seed quality, the type and proportion of the substrate (physical, chemical and biological components), management of the seedlings in the nursery as well as other aspects such as container volume.

In this study, the highest average values of SDM and RDM were observed in the treatments that presented concentrations $\leq 60 \%$ of biosolide and / or bovine manure with the organic components. Some native forest species have also presented greater production of dry biomass with use of biosolids. The species Chamaecrista desvauxii obtains higher gain of shoot and root dry mass by utilizing 60\% of biosolid as a constituent of the substrate along with other residues for its aeration (CALDEIRA et al., 2013). The legume species Senna alata also shows shoot and root gain with the use of substrate with $60 \%$ of biosolids in its constitution along with cattle manure and material for aeration (FARIA et al., 2013). As well as biosolids, the use of cattle manure presents important characteristics to the initial growth of some forest species, for in the production of seedlings of Umbu (Spondias tuberosa Arruda Câmara) substrates containing this residue provide the highest values in height of the shoot and MSR, the use of $40 \%$ of cattle manure, $45 \%$ of subsoil and $15 \%$ sand being recommended (CRUZ et al., 2016).

In the current study, the lowest mean of the root dry mass found in T5 can be accounted for by increased water-holding capacity of its substrate (Table 3), which requires greater rigorousness in controlling irrigation due to the greater possibility of waterlogging and consequently accumulation of $\mathrm{CO}_{2}$ and reduction of the aeration of roots. The root dry mass is another important characteristic to estimate the survival rate and initial growth of seedlings in the field. Delarmelina et al. (2013), when evaluating the initial growth of seedlings of Sesbania virgate, found that primary roots and young roots breathe very intensely and for these roots the oxygen necessary to the respiratory process comes from the substrate itself.

The total dry mass and the ratio between the shoot dry mass and root dry mass provide a quantitative and qualitative analysis of the distribution of these morphological characteristics of seedling growth. With regard to RSR in the present study, the treatments T2, T3 and T4 resulted in a ratio close to 1.65, indicating balance in 
the gain of shoot and root masses (Table 4). For this ratio, some researchers suggest values smaller than or equal to 2.0 for some species, as being the best ratio between these two characteristics (CALDEIRA et al., 2013; FARIA et al., 2013).

The joint analysis of the effects of the substrates on the morphological characteristics is important because it allows the grouping of the treatments according to their growth performance. In the principal component analysis (PCA), the highest correlation of treatments T2, T3 and T4 with the characteristics H, D, RHD, SDM, RDM, TDM and DQI (Figure 1) confirm the best growth of the seedlings developed in these substrates.

In addition, in spite of biosolid and cattle manure being important organic residues in the growth of forest seedlings, they need the addition of other components in order to give balance between the supply of nutrients and the physical conditions such as aeration and water retention. Due to the character presented by the morphological characteristics of the seedlings evaluated in the work at issue, it is inferred that the increase in the percentage of coconut fiber in the composition of the substrates could contribute further to the increased growth of the seedlings of $M$. polymorphum, balancing better the physical and chemical properties of the formulated substrates.

\section{CONCLUSION}

- The substrates formulated based upon the organic components biosolid, cattle manure and coconut fiber can be utilized for the production of seedlings of $M$. polymorphum in tubes. Nevertheless, for this species, substrates with proportions of biosolid or cattle manure equal or higher than $80 \%$ are not recommended.

- For the production of seedlings of the species M. polymorphum, substrates formulated with 60 to $20 \%$ de biosolid +60 to $20 \%$ of cattle manure $+20 \%$ of coconut fiber are recommended.

- For the production of seedlings of $M$. polymorphum, it is not recommended substrates with high electrical conductivity for chemical property and excessive water retention capacity for physical property.

\section{REFERENCES}

ABREU, A. H. M.; LELES, P. S. S.; MELO, L. A.; OLIVEIRA, R. R.; FERREIRA, D. H. A. A. Caracterização e potencial de substratos formulados com biossólido na produção de mudas de Schinus terebinthifolius Raddi. e Handroanthus heptaphyllus (Vell.) Mattos. Ciência Florestal, Santa Maria, v. 27, p. 1179-1190, 2017 a.

ABREU, A. H. M.; MARZOLA, L. B.; MELO, L. A.; LELES, P. S. S.; ABEL, H. L. S.; ALONSO, J. M. Urban solid waste in the production of Lafoensia pacari seedlings. Revista Brasileira de Engenharia Agrícola e Ambiental, Campina Grande, v. 21, p. 83-87, 2017 b.

ALVARES, C. A.; STAPE, J. L.; SENTElHAS, P. C.; GONÇALVES, J. L. M.; SPAROVEK, G. Köppen's climate classification map for Brazil. Meteorologische Zeitschrift, Stuttgart, v. 22, p. 711-728, 2013.

BRASIL. Resolução CONAMA n 375/2006, de 29 de agosto de 2006. Ministério do Meio Ambiente, Conselho Nacional de Meio Ambiente, CONAMA.

CABREIRA, G. V.; LELES, P. S. dos S.; ALONSO, J. M.; ABREU, A. H. M.; LOPES, N. F.; SANTOS, G. R. Biossólido como componente de substrato para produção de mudas florestais. Floresta, Curitiba, v. 47, n. 2, p. 165-176, 2017.

CALDEIRA, M. V. W.; DELARMELINA, W. M.; PERONI, L.; GONÇALVES, E. O.; SILVA, A. G. Lodo de esgoto e vermiculita na produção de mudas de eucalipto. Pesquisa Agropecuária Tropical, Goiânia, v. 43, p. 155-163, 2013.

CARLOS, L.; VENTURIN, N.; MACEDO, R. L. G.; HIGASHIKAWA, E. M.; GARCIA, M. B.; FARIAS, E. S. Crescimento e nutrição mineral de mudas de pequi sob efeito da omissão de nutrientes. Ciência Florestal, Santa Maria, v. 24, p. 13-21, 2014.

CARNEIRO, J. G. Produção e controle de qualidade de mudas florestais. Curitiba: Universidade Federal do Paraná. Campo dos Goytacazes: Universidade Estadual do Norte Fluminense, 1995.

CRUZ, F. R. S.; ANDRADE, L. A.; FEITOSA, R. C. Produção de mudas de umbuzeiro (Spondias tuberosa Arruda Câmara) em diferentes substratos e tamanho de recipientes. Ciência Florestal, Santa Maria, v. 26, p. 6980, 2016.

DE BOODT, M.; VERDONCK, O. The physical properties of the substrates in horticulture. Acta Horticulturae, Belgium, v. 26, p. 37-44, 1972. 
DELARMELINA, W. M.; CALDEIRA, M. V. W.; FARIA, J. C. T.; GONÇALVES, E. O. Uso de lodo de esgoto e resíduos orgânicos no crescimento de mudas de Sesbania virgata (Cav.) Pers. Agroambiente, Boa Vista, v. 7, p. 184-192, 2013.

DELARMELINA, W. M.; CALDEIRA, M. V. W.; FARIA, J. C. T.; LACERDA, L. C. Uso de resíduo orgânico em substrato para produção de Chamaecrista desvauxii (Collad.) Killip var. latistipula (Benth.). Cerne, Lavras, v. 21, p. 429-437, 2015.

DIAS, T. J.; PEREIRA, W. E.; CAVALCANTE, L. F.; RAPOSO, R. W. C.; FREIRE, J. L. O. Desenvolvimento e qualidade nutricional de mudas de mangabeiras cultivadas em substratos contendo fibra de coco e adubação fosfatada. Revista Brasileira de Fruticultura, Jaboticabal, v. 31, p. 512-523, 2009.

DICKSON, A.; LEAF, A. L.; HOSNER, J. F. Quality appraisal of while spruce and white pine seedling stock in nurseries. Forestry Chronicle, Mattawa, v. 36, n. 1, p. 11-13, 1960.

FARIA, J. C. T.; CALDEIRA, M. V. W.; DELARMELINA, W. M.; LACERDA, L. C.; GONCALVES, E. O. Substratos à base de lodo de esgoto na produção de mudas de Senna alata. Comunicata Scientiae, Bom Jesus, v. 4, p. 342-351, 2013.

GONÇALVES, J. L. M.; SANTERELli, E. G.; NETO, S. P. M.; MANARA, M. P. Produção de mudas de espécies nativas: substrato, nutrição, sombreamento e fertilização. In: GONÇALVES, J. L. M., BENEDETTI, V. (Eds.). Nutrição e fertilização florestal, Piracicaba: ESALQ/USP, v. 1, p. 309-350, 2000.

MACHADO, D. F. M.; TAVARES, A. P.; LOPES, S. J.; SILVA, A. C. F. Trichoderma spp. na emergência e crescimento de mudas de cambará (Gochnatia polymorpha (Less.) Cabrera). Revista Árvore, Viçosa, v. 39, p. 167-176, 2015.

MALAVOLTA, E. Manual de nutrição mineral de plantas. São Paulo: Editora Agronômica Ceres, 2006. 638 p.

SANTOS, F. E. V.; KUNZ, S. H.; CALDEIRA, M. V. W.; AZEVEDO, C. H. S.; RANGEL, O. J. P. Características químicas de substratos formulados com lodo de esgoto para produção de mudas florestais. Revista Brasileira de Engenharia Agrícola e Ambiental, Campina Grande, v. 18, p. 971-979, 2014.

SCIVITTARO, W. B.; SCIVITTARO, W. B.; SANTOS, K. F. dos S.; CASTILHOS, D. D.; CASTILHOS, R. M. V. Caracterização física de substratos elaborados a partir de resíduos agroindustrias. Pelotas: Embrapa Clima Temperado, 2007.

SOUZA JUNIOR, L.; WENDLING, I.; CUNHA, A. C. M. C. M.; ROSA, L. S.; QUOIRIN, M. Substratos e planta matriz na sobrevivência e crescimento de mudas de cambará. Embrapa Florestas. Comunicado técnico $148,2005$.

STORCK, E. B.; SCHORN, L. A.; FENILLI, T. A. B. (2016). Crescimento e qualidade de mudas de Eucalyptus urophylla x Eucalyptus grandis em diferentes recipientes. Floresta, Curitiba, v. 46, p. 39-46, 2016.

TRAZZI, P. A.; CALDEIRA, M. V. W.; COLOMBI, R.; PERONI, L.; GODINHO, T. O. Estercos de origem animal em substratos para a produção de mudas florestais: atributos físicos e químicos. Scientia Forestalis, Piracicaba, v. 40, p. 455-462, 2012.

WENDLING, I.; GUASTALA, D.; DEDECEK, R. Características físicas e químicas de substratos para produção de mudas de Ilex paraguariensis St. Hil. Revista Árvore, Viçosa, v. 31, p. 209-220, 2007.

ZORZETO, T. Q.; DECHEN, S. C. F.; ABREU, M. F.; FERNANDES JÚNIOR, F. Caracterização física de substratos para plantas. Bragantia, Campinas, v. 73, p. 300-311, 2014. 